\title{
LUD, HONOR I WŁADZA
}

\section{JAŚMINA KORCZAK-SIEDLECKA, PRZEMOC I HONOR W ŻYCIU SPOLECZNYM WSI NA MIERZEI WIŚLANEJ W XVI-XVII WIEKU}

\author{
Michał Rauszer \\ Uniwersytet Warszawski
}

Tematem omawianej w niniejszej recenzji książki są tytułowe honor i przemoc na wsiach Mierzei Wiślanej. Układ pracy jest następujący: po wprowadzeniu otrzymujemy przegląd literatury dotyczącej przemocy i honoru. W części pierwszej autorka analizuje relacje przemocy z honorem w badanych miejscowościach. W drugiej zaś zajmuje się znaczeniem obu tych wartości dla kształtowania się relacji międzyludzkich, przy czym pojęcie „honor” rozumie szerzej niż to ogólnie przyjęte. Potocznie bowiem kojarzymy go z honorem rycerskim czy honorem jako cechą moralną właściwą osobom z klas wyższych. Zamiast tego Jaśmina Korczak-Siedlecka rozumie go jako rodzaj podmiotowości jednostkowej, społecznej reprezentacji danej osoby, która ma znaczenie w budowaniu relacji społecznych, pozycji, autorytetu, a także relacji ekonomicznych, zgodnie z zasada, że „honorowej” osobie mogę pożyczyć pieniądze, gdyż reguluje ona swoje długi1. Naruszenia tak rozumianego honoru traktowano jako przemoc, ponieważ podważały społeczna pozycję danej osoby, jej wiarygodność i autorytet. Kiedy do tego dochodziło, poszkodowany lub poszkodowana udawali się do sądu, dzięki czemu autorka pozyskała sporo ciekawego materiału źródłowego.

\footnotetext{
1 Warto tutaj zwrócić uwagę na klasyczną pracę Pierre’a Bourideu Poczucie honoru (2007).
} 
Trudno jednak powiedzieć, że praca Korczak-Siedleckiej jest przełomowa. Wbrew temu, że historia społeczna, historia antropologizująca czy mikrohistoria są w Polsce mało popularne, od lat ukazują się publikacje, które $z$ powodzeniem można w te ramy ująć. I są to prace na ogół dobre. Podobnie jest $z$ tematyką chłopska. Nie był i nie jest to temat najmodniejszy, co jakiś czas jednak ukazuje się książka, której przedmiotem są chłopi (zob. np. Beauvois 2006; Bukraba-Rylska 2013; Ślusarska 1998). Monografia Korczak-Siedleckiej ma jednak sporo walorów, które pozwalają stwierdzić, że nie tylko warto sięgnać po tę pozycję, ale że powinniśmy po nią sięgać regularnie, by co jakiś czas odświeżyć sobie jej treść.

Od czasu wydania książki Adama Leszczyńskiego Ludowa bistoria Polski obserwujemy w naszym kraju wzrost zainteresowania tematyką chłopska (zob. Pobłocki 2021; Rauszer 2021). Wzrost ten jest na tyle istotny, że mówi się już o „zwrocie ludowym”, choć określnie to nie jest do końca trafne, aczkolwiek wskazuje na pewne znaczące zainteresowanie tematyką ludową niższych warstw społeczeństwa. Prace piszące historię warstw ludowych właściwie ukazują się w Polsce od 1989 roku dość regularnie (zob. Wiślicz 2001; Guzowski 2008; Wyżga 2019), jednakże dopiero ostatnia popularność tematyki ludowej zwróciła uwagę opinii publicznej na ten dorobek naukowy, nie tylko w ramach historiografii. Praca Jaśminy Korczak-Siedleckiej, choć nie wpisuje się w „zwrot ludowy”, z pewnością rozwija obszar wiedzy o życiu wsi.

W mojej ocenie jednym z najistotniejszych walorów tej pracy jest próba ukazania znaczenia honoru. Honoru nie tyle rozumianego w sposób metafizyczny, jaki przywołuje się często w dyskursie publicznym, ile rozumianego jako integralność i podmiotowość danej osoby. Jaśmina Korczak-Siedlecka w bardzo przenikliwy sposób wydobywa z materiału historycznego, w jaki sposób taka podmiotowość osoby była naruszana, a naruszenie to określa mianem przemocy. Idąc dalej, badaczka prezentuje, że tak rozumiana przemoc pozwala ukazać i oświetlić kształtowanie się stosunków społecznych, dlatego że przez naruszenie honoru odsłania możliwość reagowania na nie. Przy tym nie dotyczy to wyłącznie relacji między w miarę równymi sobie sąsiadami. Pokazuje to, w jaki sposób kształtowały się relacje władzy (klasowe, patriarchalne), bo ten, kto mógł bez konsekwencji naruszać honor innych, znajdował się wyżej w hierarchii. Pokazuje to także, jak kształtował się opór wobec relacji władzy, ponieważ ci, którzy na naruszenia swojego honoru reagowali, podważali monopol władzy na przemoc, wykorzystując do tego przeróżne narzędzia. Jest to o tyle ważne, że opór wobec władzy zawsze jest tym procesem, który powoduje, że mamy do czynienia nie tyle 
z samym uznaniem relacji władzy, ich akceptacja, ile nieustannym negocjowaniem i przesuwaniem granic tego, co władza (przeróżnie rozumiana) chce i może - podobnie jak w sprawach między sąsiadami, gdzie takie relacje władzy nie występowały. Spory o honor pokazują, jak negocjowano także własna pozycję, jak uzależniona była ona od opinii, a fakt, że sprawy te kończyły się czasem w sądzie, pokazuje, że miało to niebagatelne znaczenie.

Zasadniczy trzon bazy źródłowej stanowia księgi sądowe Mierzei i Szkarpawy, sporządzone przez administrację Gdańska należącego w omawianym okresie do Prus Królewskich. Badany przez autorkę przedział czasowy obejmuje lata 1578-1626. Wskazanie na ten zasób jest o tyle ważne, że pokazuje, jakiego rodzaju pracę wykonała badaczka. Jej przedmiotem nie jest wyłącznie historyczna rekonstrukcja stosunków na podstawie badanego materiału, ale jego analiza z perspektywy wyraźnie postawionego problemu, jakim jest prześledzenie napięć tworzących się wokół naruszenia honoru. W publikacji tej mamy więc do czynienia nie tyle z próbą dostrzeżenia w tym materiale przeźroczystego odbicia ówczesnych stosunków społecznych, ile raczej rodzajem antropologicznego podejścia do materiału historycznego, który pozwala zrozumieć, w jaki sposób kształtowały się określone stosunki oraz jakie nadawano im znaczenie. Jaśmina Korczak-Siedlecka jest świadoma, że ten dziewiętnastowieczny paradygmat opierający się na chęci opisania tego, ,jak było” w danym czasie i miejscu, który świadomie lub nieświadomie naznacza większość prac historycznych w Polsce, już dawno uległ podważeniu. Za pomocą dostępnych danych pisanych nie jesteśmy bowiem w stanie obiektywnie odtworzyć rzeczywistości społecznej, nie jesteśmy w stanie nawet się do tego zbliżyć. Materiał, z jakim mamy do czynienia, pozwala za to uchwycić dynamikę procesów, choć jest to coś innego niż ich zobiektywizowanie w rzekomo neutralnym opisie. Autorka Præ̧emocy $i$ honoru... stara się więc analizować wyrywkowy problem, który pozwala jej zrozumieć, w jaki sposób kształtowały się stosunki między ludźmi, na czym je opierano w określonym czasie. Zwłaszcza że chodzi o sposoby pozornie różne od tego, jak te stosunki kształtujemy obecnie.

Szkoda tylko, że Korczak-Siedlecka nie pokusiła się o próbę sproblematyzowania relacji między wsią czy wsiami a lokalnymi instytucjami administracji. Potoczna opinia o sprawach, jakie między mieszkańcami wsi się rozgrywały, każe myśleć, że w ich przypadku odwołanie się do jakiejkolwiek instytucji administracji, czy to państwowej, czy innej, wchodziło w grę wyłączenie w ostateczności. Wiele badań nad chłopami (czy sze- 
rzej - mieszkańcami wsi) na świecie wskazuje, że jednym z najistotniejszych czynników wywołujących ich opór było właśnie mieszanie się instytucji w ich sprawy ${ }^{2}$. Za niedopuszczalne poczytywano powoływanie się na instytucję przy rozwiązywaniu kwestii, jakie powinno się rozwiązywać między sobą. Warto by się więc zastanowić, co sprawiało, że na Mierzei Wiślanej do sądu udawano się ze sprawami dotyczącymi sąsiedzkich obelg i utarczek słownych. Co więcej, intuicja wskazuje, że odwołanie się w sporach sąsiedzkich do instytucji zewnętrznych może znacząco wpłynąć na lokalne i sąsiedzkie więzi.

Odpowiedzi na te pytania trudno oczekiwać od pracy, która miała uprzednio określona strukturę i przemyślany tok wywodu, jednakże w trakcie całej lektury gdzieś takie pytania nieustannie się pojawiały. Należy także zwrócić uwagę, że autorka daje się prowadzić przez źródła, nie odczytuje ich tak, jak „powinno się” je w danym momencie odczytywać. Zamiast tego stara się raczej zrozumieć znaczenie poszczególnych problemów dla zaangażowanych w nie osób. Dlaczego sprawa nazwania sąsiada „szelmą i złodziejem łososi” trafia do sądu? W ramach jakiego systemu symbolicznego obelga ta ma tak wielką wagę? Jak ją rozumieć? Jaśmina Korczak-Siedlecka przystępuje do tych pytań z precyzją historyczki i etnograficznym uchem, pozwalającym wykroczyć daleko poza zwykłe sprawozdanie z tego, co udało się znaleźć w archiwum.

Dostrzegam jednak w niektórych miejscach omawianej pracy pewien brak antropologicznego wyrobienia, zdaje się będącego pochodną traktowania antropologii przez środowisko historyczne po macoszemu. W niektórych fragmentach autorka na poparcie swoich tez wydaje się dość przypadkowo brać za podstawę koncepcje należące już raczej do historii myśli antropologicznej. Przykładowo w części pierwszej podaje różne rodzaje werbalnej przemocy, takie jak oszczerstwo, szyderstwo, plotka, groźba czy przekleństwo. Jako podstawę rozumienia znaczenia tychże wskazuje zasady magicznego myślenia, opierając się na pracach Bronisława Malinowskiego (działanie za pomocą słowa) oraz teorii performatywnej aktów mowy. Badaczka twierdzi, że problem polegał na tym, że kiedy ktoś wypowiada na przykład obelgę: „ty złodzieju flądry”, tym samym stwarza w publicznym obrazie pewne wyobrażenie na temat danej osoby. Wobec takiej obelgi wytaczano zatem procesy, które miały ten obraz zmazać. Korczak-Siedlecka dochodzi do wniosku, że słowa te miały znaczenie „magiczne”, stwarzały

\footnotetext{
2 W badaniach nad chłopskimi ruchami istnieje cały nurt zajmujący się oporem chłopów wobec ingerencji ze strony państwa i instytucji. Wymienia się tutaj takich badaczy, jak Eric R. Wolf, James C. Scott i innych. Zob. Jenkins 1983.
} 
pewną rzeczywistość, którą sąd miał unieważnić (czy też skazać obrażającego na „odszczekanie” takich słów).

Można wobec tego podnieść pewne zastrzeżenia. Mianowicie założenie to opiera się na przekonaniu, zaczerpniętym zresztą między innymi z prac wskazanego Malinowskiego, że słowo w kulturach „tradycyjnych” ma magiczną moc, to znaczy - jest tożsame z działaniem. Kiedy wypowiadam coś, to tak, jakbym to stwarzał. Pierwszym problemem jest tutaj problem $z$ danymi. Malinowski, tak jak inni antropolodzy, zbierał je $w$ trakcie badań terenowych, ale mimo wszystko były one zapośredniczone przez tłumaczy. Powoduje to, że czasem bierze się pewne sformułowania zbyt dosłownie, co powoduje, że powstaje wrażenie, jakby „dziki” (jak pisał sam Malinowski) rzeczywiście wierzył w to, kiedy my, racjonalne, oświecone podmioty, wiemy, że jest inaczej. Tymczasem gdyby zbadać kontekst żywego użycia słowa, mogłoby się okazać, że tezy o „magicznej” mocy słów są nieco na wyrost, a sprawa jest trochę bardziej skomplikowana. Wskazywało na to zreszta wielu badaczy i badaczek tego zagadnienia po Malinowskim (zob. Engelking 2010; Buchowski 1993; Kajfosz 2009).

W przypadku pracy Jaśminy Korczak-Siedleckiej mamy do czynienia z danymi pozyskanymi z protokołów postępowań administracyjnych. Kontekst zbierania danych jest więc tutaj zasadniczo odmienny i bardzo trudno wyrokować o realnym sposobie funkcjonowania tego typu słów (obelgi, przekleństwa). Po prostu nawet dzisiaj człowiek w kontakcie z administracją zachowuje się inaczej niż w codziennej rozmowie, nawet jeżeli ta rozmowa jest kłótnią. Problem polega na tym, że może nie tyle chodzić o to, że obelżywe słowa „stwarzaja”" w publicznej przestrzeni coś, jakiś fałszywy obraz, ile o coś zupełnie przeciwnego - może plotki, oszczerstwa i inne ujmują honoru, pomniejszaja go u danej osoby? Wartość ta rozumiana jest tu przecież, jak sama autorka wskazuje, jako rodzaj społecznego kredytu zaufania, a to przecież na podstawie publicznej „opinii” o honorze danej osoby budowany był jej autorytet, pozycja społeczna, a więc także możliwości społeczne. Być może w procesach wytaczanych o zniesławienie nie chodzi o usunięcie stworzonego (magicznie) za pomocą słowa obrazu danej osoby, ale o „oddanie” zabranego za pomoca zniesławienia kawałka honoru? Są to jednak kwestie nie tyle podważające wartość pracy, ile otwierające wobec niej dyskusję.

Pisząc kilka akapitów wcześniej o tym, że autorka rekonstruowała, w jaki sposób kształtowane były stosunki między ludźmi, podkreśliłem, że chodziło o sposoby „pozornie” różne od naszych. Czy zatem taki sposób rozumienia honoru i przemocy, jaki opisała Korczak-Siedlecka, nie rezonu- 
je także w naszych czasach? Jeżeli spojrzymy na mury wielu polskich miast, zobaczymy, jak usilnie kibice przeciwnych drużyn starają się „podważyć” honor innych i jakie znaczenie ma dla nich obrona tego honoru. Jeżeli zaś spojrzymy na filmy traktujące o środowiskach mafijnych, dostrzeżemy, że sporo z nich za oś narracji wybrało właśnie próbę rehabilitacji czy odwetu za splamienie honoru, a osoby, których one dotyczą, wcale $z$ arystokracji się nie wywodziły. Kiedy czytałem strony pracy Jaśminy Korczak-Siedleckiej dotyczące obrazy na tle seksualnym, od razu przypominała mi się scena z serialu Rodzina Soprano, kiedy jeden z bohaterów i członek mafii pobił swoja partnerkę za wyjawienie, iż odbył z nią cunnilingus. Okazało się wówczas, że w środowisku gangsterów było to traktowane jak obelga, podważało jego honor i pozycję jako mężczyzny.

Takie prace jak ta autorstwa Jaśminy Korczak-Siedleckiej powinniśmy jednak czytać, bo nie tylko pozwalaja one zrozumieć coś z przeszłości, ale dają także podstawy rozumienia teraźniejszości. Ta konkretna publikacja wprowadza między innymi na nowo pojęcie honoru (rozumianego jako podmiotowość) w obszar naszych zainteresowań, pozwala zrozumieć, jakie znaczenie w różnych środowiskach ma budowana o nas opinia, poparta stosownym zachowaniem, i jak wielkie znaczenie może mieć utrata choćby cząstki dobrego imienia. Poza tym jest to solidnie przygotowana monografia historyczna, mocno osadzona w antropologii czy socjologii historycznej, napisana przy tym z dużą swobodą i znajomością rzeczy.

Bibliografia:

/// Beauvois D. 2006. Trójkeat ukrainski. Szlachta, carat i lud na Wolyniu, Podolu i Kijonsz̧飞yźnie 1793-1914, tłum. K. Rutkowski, Wydawnictwo UMCS.

/// Bourideu P. 2007. Poczucie honoru, [w:] tegoż, Szkic teorii praktyki poprzedzony trzema studiami na temat etnologii Kabylón, tłum. W. Kroker, Wyd. Marek Derewiecki.

/// Buchowski M. 1993. Magia i rytuat, Wyd. Instytut Kultury w Warszawie. /// Bukraba-Rylska I. 2013. Socjologia wsi polskiej, Wydawnictwo Naukowe PWN.

/// Engelking A. 2010. Klatwa. Rzecz o ludowej magii stowa, Oficyna Naukowa. 
/// Guzowski P. 2008. Chtopi i pieniadze na przetomie średniowiecza i czasón nowo żytnych, Avalon.

/// Jenkins C. 1983. Why do Peasants Rebel? Structural and Historical Theories of Modern Peasant Rebellions, „American Journal of Sociology” 88, nr 2, s. $487-514$.

/// Kajfosz J. 2009. Magia w potocznej narracji, Wydawnictwo Uniwersytetu Śląskiego w Katowicach.

/// Korczak-Siedlecka J. 2001. Przemoc i honor w życiu spotecznym wsi na Mierzei Wislanej w XVI-XVII wieku, Wyd. FNP.

/// Pobłocki K. 2021. Chamstwo, Wydawnictwo Czarne.

/// Rauszer M. 2021. Sita podporzqdkowanych, Wydawnictwa Uniwersytetu Warszawskiego.

/// Ślusarska M., red. 1998. Dwór-plebania-rodzina chtopska. Szkice z. dziejów wsi polskiej XVII-XVIII wieku, DiG.

/// Wiślicz T. 2001. Zarobić na duszne zbawienie. Religijność chtopów małopolskich od polowy XVI do końca XVIII wieku, Neriton.

/// Wyżga M. 2019. Homo Movemens. Mobilność chtopów w mikroregionie krakowskim XVI-XVIII wieku, Wydawnictwo Naukowe Uniwersytetu Pedagogicznego w Krakowie.

/// Michał Rauszer - kulturoznawca i antropolog. Pracuje na Wydziale Pedagogicznym Uniwersytetu Warszawskiego. Specjalizuje się w badaniach i pisaniu o oporze, buntach oraz sytuacji osób podporządkowanych. Jest autorem monografii Homo Frajer. Nieswiadome wymiary kultury (2014), Bęarty pañsz̨zyzny (2020) oraz Siła podporzqdkowanych (2021).

ORCID: https://orcid.org/0000-0003-4956-4256

E-mail:mrauszer@gmail.com 